\title{
BioéthiqueOnline
}

\section{The Dalhousie Dentistry Story: A Case for Proportionality, Professionalism, and the Promotion of Moral Character}

\section{Cécile M. Bensimon}

Volume 4, 2015

Reçu : 22 Jan 2015; publié : 27 Jan 2015

URI : https://id.erudit.org/iderudit/1035488ar

DOI : https://doi.org/10.7202/1035488ar

Aller au sommaire du numéro

Éditeur(s)

BioéthiqueOnline

ISSN

1923-2799 (numérique)

Découvrir la revue

Citer ce document

Bensimon, C. M. (2015). The Dalhousie Dentistry Story: A Case for

Proportionality, Professionalism, and the Promotion of Moral Character.

BioéthiqueOnline, 4. https://doi.org/10.7202/1035488ar 


\title{
The Dalhousie Dentistry Story: A Case for Proportionality, Professionalism, and the Promotion of Moral Character
}

\author{
LA TRIBUNE DE L'ÉDITEUR / EDITOR'S SOAPBOX \\ Cécile M. Bensimon ${ }^{1,2}$
}

Reçu/Received: 22 Jan 2015

Publié/Published: 27 Jan 2015

2015 CM Bensimon, Creative Commons Attribution 4.0 International License

\section{Mots clés}

Dalhousie, dentisterie, sexisme, harcèlement, inconduite, proportionnalité, professionnalisme, caractère moral
Keywords

Dalhousie, dentistry, sexism, harassment, misconduct, proportionality, professionalism, moral character

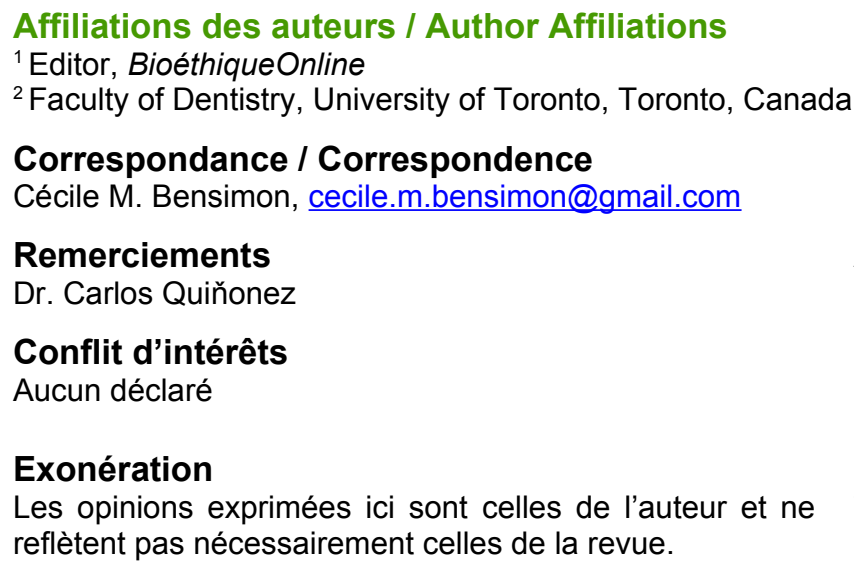

\author{
Acknowledgements \\ Dr. Carlos Quiňonez \\ Conflicts of Interest \\ None to declare

\section{Disclaimer} \\ The views expressed here are the author's and do not \\ necessarily reflect those of the journal.
}

The well-publicised and much-discussed crisis at the Dalhousie Faculty of Dentistry has gripped the dental profession in Canada - and rightly so.

The fate of the senior male students at the heart of the crisis - fourth-year students one semester short of becoming professional dentists, with all the profession's obligations and privileges - has been the subject of ferocious debate. What they have posted on social media is unquestionably reprehensible and indefensible. ("Who would you hate fuck", they quipped about their own female colleagues, while casually considering which anaesthetic to use to sedate women to submit to sex). Indeed, they seemed impervious to the increasing conversation, perhaps even a semblance of a collective consciousness, about sexual violence against women that was (re)ignited on the heels of the Jian Ghomeshi scandal. And - more fundamentally - that the profession of dentistry presupposes a commitment to professional norms of conduct and public expectations, appears to have been completely lost on them. Following a domino of events, they have been suspended from clinical activities and classes, while the University proceeds with a formal review of the incident and a controversial process of restorative justice (a face-to-face mea culpa with the victims).

What is an appropriate response to this? Why does it require a response? Why has it galvanised such a spectacular stand against the male students' right to freedom of speech in favour of women's right to live free from sexual violence? And, most crucially, what can we learn from it? Even if none of the 13 men had any intention of enacting their disturbing fantasies, what they said matters. Words matter. Behind words, violent words, are ideas that underpin deep-seated beliefs about and form the fabric of the society we live in. What these men did - to engage in what they surely thought was benign bantering on Facebook - categorically requires consequences. Proportional consequences. 
The principle of proportionality is invoked in many contexts: in public health (whether the benefits of an intervention outweigh the infringed-upon morally-relevant considerations, i.e., rights); in research (where any potential harm to a participant should not be disproportionate to the potential benefits for society); and as a legal principle (where it aims to measure the appropriate relationship between the ends and the means of an action). While there is no universal definition of proportionality, the basic meaning, in essence, is balance, equilibrium; the balance between harm and remedy, between benefits and burdens.

The expulsion of the 13 Dalhousie male students, as so many have forcefully advocated, including in a 50,000-strong petition, would not be, by all reasonable accounts, a proportional response or in any way constructive. Thirteen dental students made a mistake, a damning mistake. Such a gross error in judgement requires remedial action and education, not expulsion. Every self-regulated profession has thorough disciplinary processes that engage offending practitioners in the process of redress and rehabilitation. For example, how many disciplinary proceedings and citations are dentists granted before having their license revoked? Expelling these students, essentially doing away with them, does not address the root of the problem, nor does it teach much to the students themselves. "To make the punishment fit the crime," as some have suggested [1] - so let's be clear about who's and what crime it is. This did not occur in a vacuum, but rather in a context of social complicity and society's unbridled misogyny, and inadequate education about what it means to be a professional.

The roots of the Dalhousie crisis run deeper than the students' behaviour. It has laid bare - or, as an editorialist said, "the sheet has been pulled back on" [2] - the deeply-rooted misogynistic attitudes that still persist at the heart of society today. As one editorialist aptly summarised: "We have seen rape chants erupt on campuses from UBC to Saint Mary's; we've noted the denigrating tweets and rape threats against women on social media; we've exposed the long-running reign of terror against women by Jian Ghomeshi; we've heard men cat-calling and abusing women on the floor of the House of Commons; we've had the tragic case of Rehtaeh Parsons" [3]. And there's more. We have only recently begun challenging sexism in video games and the gaming industry (for which some women have received rape and death threats). Violent and misogynistic lyrics have become normalised in the mainstream music industry. And women recoil at the idea of having to formally report sexual harassment or sexual violence without mechanisms guaranteeing anonymity because they know, we all know, that the repercussions are often greater than not reporting.

Closer to home, it has been reported that informal complaints had already been lodged on behalf of women who experienced harassment and what they considered to be preferential treatment of male students at the Dalhousie Faculty of Dentistry [4]; the same Faculty were female students reported that a male professor showed a video featuring Sports Illustrated swimsuit models to "wake up the men in the class" [5] (Seriously?). What is more, a few days after the Dalhousie Class of DDS 2015 Gentlemen's group was outed, news surfaced that the Manitoba Faculty of Dentistry had quietly dealt with similar inappropriate misogynistic conduct after a female graduate dental student filed a formal complaint and hired a lawyer [6].

The Dalhousie crisis may have exposed deep divisions in what a former adjunct professor at UBC's Faculties of Law and Dentistry called a "far larger boys' club problem" in the seemingly "white male bastion" of the leadership of the Canadian dental profession and dental education [7]. This is an interesting observation in light of the increasing proportion of women in dentistry since the 1970's, pointing to what has been observed as "the feminization of dentistry" [8] and the potential effects this shift is having on the profession, the (re)shaping of its values, and the nature of the dentist-patient relationship [9]. All of this presents circumstances that are propitious for considering issues of professionalism and ethics. As an editorialist observed, this is an opportunity to turn "an ugly moment" into a "teachable one." [10]. Yes, it is. The Dalhousie crisis and the "changing face of dentistry" [11] positively raise deeply-important questions about what it means to be a professional, what constitutes adequate professional education, and why moral character is, or ought to be, a professional credential. 
Perhaps the most interesting aspect that has come out of the Dalhousie story are the provincial regulators who report they will take additional steps to ensure that dental graduates from the Dalhousie Class of DDS 2015 are of "good character" [12]. This raises questions ripe for analysis and action. Why are they pointing to character? Does the profession of dentistry have substantive character requirements? On what basis ought we assess character? Does prior conduct have predictive power?

Beginning a substantive conversation about moral character and whether, or why, it ought to be a professional credential is very promising. It is a concept that gets to the heart of professionalism. Historically, the origins of professionalism, or of the formalisation of professional culture, derived from the evolution of character standards as a requirement for the certification of a professional. In law, for example, the central premises of character review are the protection of the public and the upholding of professionalism [13]. Today, every profession articulates expectations of how members of that profession ought to behave. Character, in short, is a moral condition of professionalism.

Focusing on character assessment at the end of one's education or as a form of continuing education, however, may be too late. Moral lapses do not derive from inherent moral failings, as many would have us believe. These largely stem from inadequacies in the education students receive in preparation for professional life. Education about professionalism ought to start at the beginning of one's professional education - or, as sociologists call it, professional socialization. It is now widely accepted that professional education alone does not promote character development or reasoning development and thus does not provide sufficient guidance or sufficient moral suasion on what it means to be, and what are the obligations of, a professional. Studies in dentistry have shown that change in moral judgement and cognitive problem-solving ability in ethical decision-making could be positively attributed to the introduction of an ethics curriculum $[14,15]$. As such, education about professionalism and professional practice ought to be integrated into professional education.

As for the 13 Dalhousie dental students, a formal ethics education that clarifies and articulates important values of professionalism, and of becoming a professional dentist, would go a long way. Much farther, in fact, then tossing them to the curb and ignoring, or even minimising, the systemic broader issues that propel, or compel, anyone to act so, well, unprofessionally.

\section{List of References}

1. National Post Editorial Board. To make the Dalhousie dental students' punishment fit the crime. The National Post, 6 January 2015.

2. Lowe L. Safe, private way needed to report sexism, The Chronical Herald, 9 January 2015.

3. Haiven J. The 'middle road' won't do for Dalhousie's 'gentlemen' dentists, Rabble.ca, 24 December 2014.

4. CBC News. Dalhousie dentistry complaints date back to summer, student says, CBC.ca, 16 December 2014.

5. CBC News. Dalhousie dentistry student speaks out about sexism in faculty, CBC.ca, 17 December 2014.

6. Coubrough J. Misogyny complaints emerge from Manitoba dentistry program, CBC.ca, 22 December 2014.

7. Rush J. Dentistry has a far larger 'boys' club' problem, The Globe and Mail, 24 December 2014.

8. Adams TL. Feminization of professions: The case of women in dentistry. Can J Sociology. 2005;30(1):71-94.

9. McKay J., Quiňonez CR. The feminization of dentistry: Implications for the profession, J Can Dent Assoc. 2012;78(c1).

10. Globe Editorial. Dalhousie's handling of Facebook scandal is the right way to go, The Globe and Mail, 5 January 2015. 
11. Embrett C. The changing face of dentistry. Ontario Dentist. 2014;91(7):16-18.

12. Chiose $S$. Dalhousie dentistry students scrambled to contain damage after comments became public. The Globe and Mail, 6 January 2015.

13. Rhode DL. Moral character as a professional credential. Yale Law Journal. 1985;491-603.

14. Bebeau MJ. The defining issues test and the four component model: Contributions to professional education. J Moral Educ. 2002;31(3):271-295.

15. Bebeau MJ, Thoma SJ. The impact of a dental ethics curriculum on moral reasoning. $J$ Dental Educ. 1994;58(9):684-692. 